\title{
Relative Economic Efficiency of Mechanized and Non-Mechanize Rice Farmers in Nasarawa State, Nigeria.
}

\author{
Suleiman H.R ${ }^{1}$, Ibrahim H., \\ ${ }^{I}$ Department of Agric and Natural Resources, Obi Local Government Area, Nasarawa State. \\ ${ }^{2}$ Department of Agricultural Economics and Extension, Nasarawa state University Keffi.
}

\begin{abstract}
This paper examined the economic efficiency of resources used in rice production among mechanized and non mechanized farmers in Nasarawa state, Nigeria. Data were collected from a randomly sample of 132 farmers (66 non-mechanized and 66 mechanized) and analyzed using gross margin, farm financial ratio and regression analysis. The result revealed a difference of $\$ 13,900$ in cost of production, $\$ 48,000$ in revenue realized, $\$ 34,100$ in gross margin and $\$ 19,100$ in net profit accrued from the used of mechanization. The coefficient of farm size and fertilizer are positive and statistically significant at $(P<0.1)$ under non mechanized rice farms, for mechanized farms, all the variables are positive and statistically significant. Mechanized rice farmers used there inputs close to economic optimum with efficiency ratio of 0.98, 0.95 and 0.94 for labour, farm size and seed respectively, compare to 0.58, 0.46 and 0.71 of the same inputs used by non mechanized rice farmers, while fertilizer 3.16 and 56.32 was under utilized for both mechanized and non mechanized. For optimum allocation of resources, labour (101.68\%), farm size (106.28\%) and seed (105.41\%) were over utilized in mechanized farms, labour (172.25\%), farm size (115.10\%) and seed (140.56\%) were over utilized in non mechanized farms and Fertilizer having (98\% and 68\%) was under utilized in both mechanized and non mechanized rice farms respectively. The results show that a lot need to be done to bridge the gap for optimum use of the resources under non mechanized rice production. The results also show that there is need for making inputs such as fertilizer affordable and accessible to the farmers so as to improve production efficiency. Also policies that encourage the use of farm machinery to absorb the excess labour cost in rice production in the study area should be formulated.
\end{abstract}

Keywords: Economic Efficiency, Economic Optimum, Optimum Allocation of Resources, Mechanization, Rice Production.

\section{Introduction}

Rice is indeed one of the world's most important food crops, being the staple food for over 50 percent of the world's population; it is particularly important in china, India and a number of other countries in Africa and Asia. Globally, rice is an important food crop and is increasingly preferred over many traditional foods, such as sorghum, millet and most root and tuber crops such as yam and cassava (Defoer et al; 2004). Rice is consumed by over 4.8 billion people in 176 countries and is the most important food crop for over 2.89 billion people in Asia, 40 million in Africa, 150.3 million people in America and over 120 million people in Nigeria (Daramola, 2005). It is also one of the major cereals to gain the status of a cash crop status in Nigeria, especially in those rice-producing areas where it provide employment for more than 80 percent of inhabitants as a result of the commercial activity that takes place along the distribution chain from cultivation to consumption (FAO, 2003). Nigeria is currently the highest rice producer in West Africa, producing an average of 3.2 million metric tons of paddy rice or 2 million of milled rice per year (Daramola, 2005). It is also the largest consuming nation in west Africa, with the growing demand amounting to 4.1 million tons of rice in 2002, with only about half of that demand met by domestic production, the growth in rice demand as a preference staple food is so strong that production intensification and higher yields per hectare will not be sufficient to fill the gap to meet rice demand (Tollens, 2006).

Agricultural production is strongly influence by the amount of factors of production and the time of applications of necessary operations. The adopters of agricultural technology were found to utilized farm size, labour and seed inputs more efficiently than the non adopters, while the reverse is holds in respect of fertilizer input. Need for more use of fertilizer exist in both adopters and non adopters but more pronounced in non adopters (Idi, 2004). It was also observed that the income and output of farmers could be improved if resources were efficiently used at the existing technology. Thus, in the short run, there lies a potential of about 28 percent to increase the output of rice by adoption of the technology and technique of best practice rice farms, while the potential therein in non mechanized farms is about 38 percent (Ajao et al; 2005). The relatively poor performance of irrigated rice schemes in the country can be attributed to a number of biophysical, socioeconomic and institutional constraints (Fagade and Nguyen, 2001). The declining self sufficiency ratio in rice production indicates that Nigeria has remained importer of rice with well over US \$267 million spent annually 
(Eke, 2008). One approach to solving Nigeria's rice production problem is to investigate the pattern of resource use among rice farms, especially small holder rice farmers, to determine what adjustment might be made to increase rice output (Olagoke, 1991). The most pressing need is to feed a growing human population. This requires sustaining food production, which can be realized by increasing land and labour efficiency in agriculture through farm mechanization. Farm mechanization is often misconstrued to mean modernization, beneficial only to industrialized countries with highly mechanized agriculture. Developing countries often have to rely on a variety of imported farm machines, which are seldom appropriate for small farms. Small size farm is a big issue when it comes to mechanization because it is against the "economic of scale" (www.agent , 2005).

The limited capacity of Nigerian rice sector to meet its domestic demand has raised a number of pertinent questions both in policy circle and among researchers some of these questions are concerned with whether or not farmers receiving remuneration profit or whether they are allocating resources efficiently in rice production (Abdullahi et al; 2012).

In this study therefore, an attempt has been made to examine the economic efficiency of resources use in mechanized and non mechanized rice production in Nasarawa state, Nigeria. The specific objectives were to;

i. determine the relationship between cost incurred and revenue accrued among mechanized and non mechanized rice farmers in the study area.

ii. Compare the efficiency of resources used by the two groups.

Iii.Identify the gap needed to be bridge for optimum use of resources among the two groups.

\section{Methodology}

Study Area: The study was conducted in Nasarawa state; the state is located in the middle belt zone of the country. It lies between latitude $7^{\circ}$ and $9^{\circ}$ North and longitude $7^{\circ}$ and $10^{\circ}$ East, and shares common boundaries with Benue state to the South, Kogi state to the West, the federal capital territory (FCT), Abuja, to the North West, Kaduna and plateau states to the North East, and Taraba state to the south East. The state has a climate typical of the tropical zone, because of its location. It climate is quite pleasant: A mean temperature of $60^{\circ} \mathrm{F}$ and $80^{\circ} \mathrm{F}$ maximum have been recorded while rainfall varies from $313.73 \mathrm{~cm}$ in some places to $145 \mathrm{~cm}$ in other areas. The month of December, January and February are cold (sometimes quite cold) due to the very dry harmattan winds blowing across the state from the North-East. It is characterized by two distinct seasons: dry and wet. The dry season start from November to February, while the rainy season is from March to October. Average daily sunshine in the state is 6.2 hours and average daily vapour pressure is $26 \mathrm{hpg}$.

The physical features of the study area are largely mountainous. It covers very large area of the state, much of which are rocky and of undulating highlands to average height of about $1,400 \mathrm{~m}$ above sea level. The coastline of river Benue and its trough created alluvial fertile soil, which is very good for crop production. Other smaller rivers cover most parts of the state and empty into the river Benue. The sediments are generally comprised of sandstones, siltstones and subordinate inter-bedded clays all of cretaceous age. Alluvial soils are found along the Benue trough and their flood plains. These are always swampy in nature due to availability of water all the year round. The forest soil, which are rich in humus, and laterite soils are found in most parts of the state.

The 1991 census put the state's population at 1.2 million. The state's population by 2003 , estimated at the national average growth rate of $2.83 \%$ per annum, is projected to 2.0 million. However, with the influx of people particularly into Karu and Keffi LGAs, due to their proximity to the federal capital territory, Abuja, as well as into Lafia, being the state capital, places the current estimated population of the state at 2,040,097 (NPC, 2006). Males constitute $51 \%$ and females $49 \%$ of the population. Over $80 \%$ of the people of the state are subsistence farmers and live in rural areas. Major crops suitable to the state ecological conditions are rice, sesame, soya beans, groundnut, cassava, yam, maize, cashew, sorghum, melon, mangoes, citrus and vegetables. There is an estimated water surface area of over 5,645 square kilometer and favourable climatic conditions for the fish industry.

Sample size and Sampling Technique: The target population for the study was mechanized and none mechanize rice farmers in Nasarawa state, the state was stratified according to the three agricultural zones (south, north and west). The sampling comprised of a two stage sampling procedure.

The first stage involved random selection of two local government areas from each agricultural zones noted for intensive production of rice from the thirteen local government areas, giving a total number of six (6) local government areas. The six local government areas noted for intensive production of rice sampled during preliminary survey were southern zone (Lafia and Awe), Northern zone (Nasarawa Eggon and Kokona) and Western zone (Karu and Toto). Stage two; the sample size used for the study was one hundred and thirty two (132) respondents, selected from both mechanized and non mechanized rice farmers, making up sixty six (66) from each group and six (6) from each of the selected local government area in the study area. Information collected from both group, bothered their inputs and outputs as well as their current market prices. Sizes of farmers' field were determined by stepping method to estimates the dimension where there is no record. 
Quantities of seed and fertilizer were measured in kilogram, herbicide in litre and labour in mandays. Fixed inputs depreciation was charged, assuming a useful life of 5 years, using straight line method.

Analytical Procedure: The gross margin analysis method was employed to determine the overall gross margin per hectare and the net farm income (NFI) per hectare. Other tools of analysis include farm financial ratio and regression model.

Gross Margin Analysis: The gross margin, the return over variable cost is an appropriate measure of profitability used for comparing enterprises for short run annual planning decision (castle, 1987). It is a very useful planning tool in farming enterprises in the case of subsistence agriculture (Olukosi and Erhabor, 1989). Johnson (1982) added that strictly speaking gross margin is the difference between the cost of production and the marginal cost of that production. Formula for gross margin;

$\mathrm{GM}=\mathrm{TR}-\mathrm{TVC}$

Where

$\mathrm{GM}=$ Gross margin

$\mathrm{TR}=$ Total revenue

$\mathrm{TVC}=$ Total variable cost.

This research will use gross margin to determine the return over variable costs per hectare for rice farm in the study area. The gross margin model used is express as;

$\mathrm{GM} / \mathrm{Ha}=$

TR - TVC

Total area of production $(\mathrm{Ha})$

Net Farm Income: This is the profit from the farmer's operation and represents the return to the owner for personal labour, management and equity capital used in the farm business (Kay, 1981). It is obtained by adjusting net cash farm income for total depreciation, net inventory changes and products consumed at home. This is the only true measure of profit for the accounting period, as net cash farm income does not include the above adjustments, which can be quite large (Kay, 1981). Olukosi and Erhabor (1988) added that the net farm income can be determined by subtracting the total fixed cost from the total gross margin of the whole farm or all the enterprises. Net farm income was calculated using the following formula;

$\mathrm{NFI}=\mathrm{GM}-\mathrm{FC}$

Where

$\mathrm{NFI}=\mathrm{Net}$ farm income

$\mathrm{GM}=$ Gross margin

$\mathrm{FC}=$ Fixed cost

This study used net farm income to determine the return on capital invested the wage for farmers' physical labour and reward for management per hectare. The net farm income model used for the study is;

Gross margin - Total fixed cost

Net farm income/Ha $=\frac{\text { Total area of production }(\mathrm{Ha})}{----(4)}$

Farm Financial Analysis: Farm financial ratios was used to determine the strength of both mechanized and non mechanized rice farmers in the study area, these ratios were gross, operating and fixed.

Gross Ratio: The gross ratio is the total farm expenses divided by the gross income. Where the total farm expenses figures is obtained by summing the operating and fixed cost figures. The gross ratio measures the ultimate solvency and success of the farm business. It is a long run planning tool for determining the performance of entire farm business. A less one ratio is desirable for farm business (Olukosi and Erhabor, 1988). The gross ratio shows the proportion of gross income that goes to pay for the expenses. The gross ratio formula for this study;

Total cost of production

Gross ratio $=\frac{\text { Total revenue }}{\text { Totat }}$

Operating Ratio: The operating ratio is the total operating cost divided by the gross income. The operating cost shows the proportion of the gross income that goes to pay for the operating cost. The operating cost which is directly related to the variable resources is the decision making tool with regards to factor adjustment during a production period. In traditional farm setting, the operating ratio is more important than fixed ratio in that most of the resources used are variable, while fixed items are almost negligible (Olukosi and Erhabor, 1988). The operating ratio formula used for this study is;

Total variable cost 
Operating ratio $=$

Total Revenue

Fixed Ratio: The fixed ratio is the total fixed cost divided by gross income. It is an indication of the percentage of the gross income accruing to the fixed resources. It is also ex ante decision tool: (Olukosi and Erhabor, 1988). The fixed ratio formula used for this study is;

Total fixed cost of production

Fixed ratio $=\frac{}{\text { Total Revenue }}$

Farm financial ratio has been used by many workers Sani (1996), Idi (1997), Suleiman (2008) to measure the financial success of farms in Nigeria. enterprise.

Return per Naira invested: is given as the net income realized on each naira invested in the rice

$$
\mathrm{RNI}=\mathrm{NFI} / \mathrm{TC}
$$

Where

$$
\begin{aligned}
\mathrm{RNI} & =\text { Return on naira invested. } \\
\mathrm{NFI} & =\text { Net farm income } \\
\mathrm{TC} & =\text { Total cost of production. }
\end{aligned}
$$

Regression Analysis Model Specification: A rice production function was estimated using regression analysis. Three functional forms were derived to estimate the rice production function in mechanized and nonmechanized operations; these functional forms were modeled in linear, semi-logarithm and double logarithm. The production function was specified as follows:

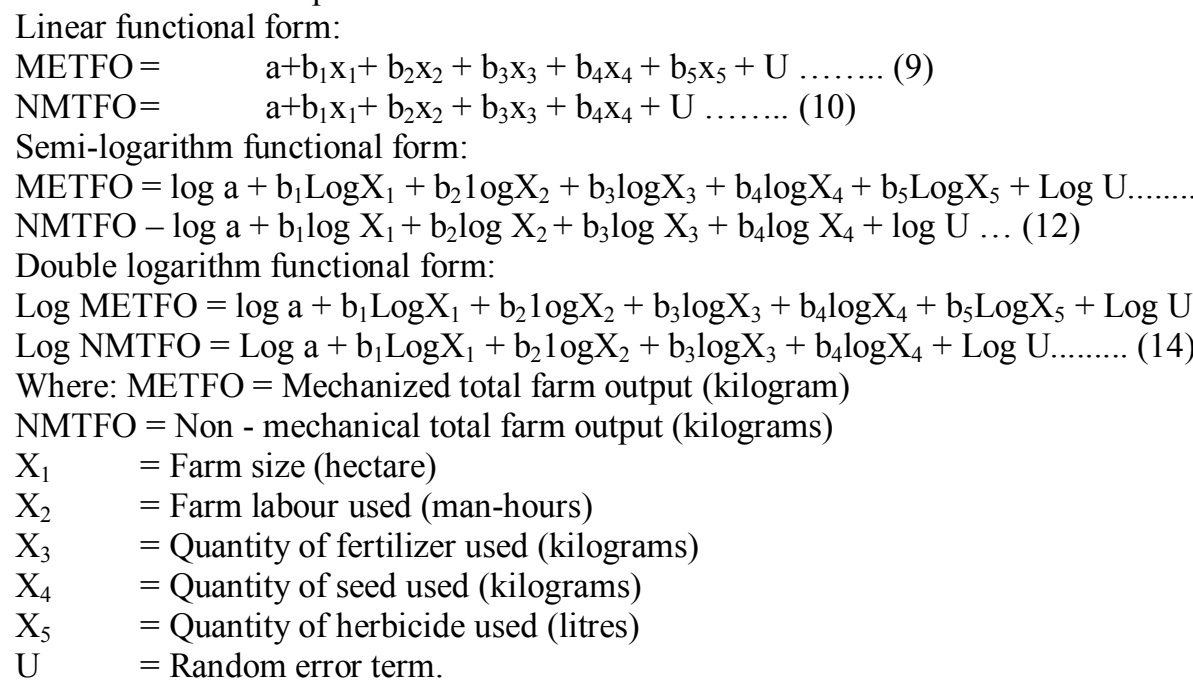

Resource Use Efficiency: Marginal value product was estimated using the regression coefficient of each input and the price of the output. The resources are said to be efficiently used if its MVP is equal to its acquisition unit price. The MVP is calculated as;

$$
r=\frac{\text { MVP }}{\text { MFC }}
$$

Where

$\mathrm{r}=$ Efficiency ratio

$\mathrm{MVP}=$ Marginal value product

$\mathrm{MFC}=$ Marginal factor cost

The resource is said to be efficient if:

$r=1$, meaning resource is being efficiently utilized.

$\mathrm{r}<1$, it means the resource in question was over utilized hence decreasing the quantity used of that resource increases profit.

$\mathrm{r}>1$, it shows that the resource is being under utilized and increasing the rate of use will raise profit level. 
Marginal Value Product Adjustment: Marginal value product (MVP) Adjustment, The relative percentage change in MVP of each resource required so as to obtain optimal resource allocation that is $r=1$ or $\mathrm{MVP}=\mathrm{MFC}$ is estimated using equation below;

1 - MFC

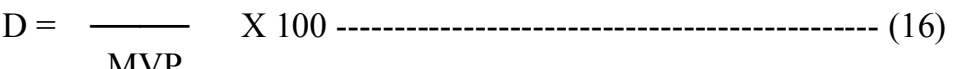

Where

$\mathrm{D}=$ absolute value of percentage change in MVP of each resource.

MVP = Marginal value product

$\mathrm{MFC}=$ Marginal factor cost

\section{Results And Discussion}

Profitability of Rice Production: The result in table 1 revealed that, the mean total cost of production per hectare were $\$ 87,600$ and $\$ 73,700$ for mechanized and non mechanized rice farms respectively, this represent a difference of $\mathrm{N} 13,900$. The mean total value of production per hectare were $\$ 144,000$ and $\$ 96,000$ for mechanized and non mechanized rice farms, representing a difference of $\$ 48,000$. The mean return over total cost of production per hectare were $\$ 56,400$ and $\$ 22,300$ for mechanized and non mechanized rice farms, representing a difference of $\$ 34,100$. While the mean net farm income per hectare were $\$ 28,200$ and $\$ 9,000$ for mechanized and non mechanized, a difference of $\$ 19,100$ was realized.

The result showed that, there is much difference in the mean total revenue realized between the two groups of farmers. This means that the level of technology does have much impact on the yield, there by much difference in the profit realized. This was expected as the non mechanized farmers had such limited access to acquire fixed capital inputs for farm expansion. Consequently, they were able to afford only rudimentary tools such as hoes, cutlasses, sickles and the like which are cheap but that could not be relied upon to expand rice production. This assertion agree with that of Ajao et al; (2005), which state that, the income of farmers could be improved if resources were efficiently used at the existing technology.

Table 1: Cost and returns analysis of Mechanized and Non Mechanized rice farmers in Nassarawa State.

\begin{tabular}{lcc}
\hline & \multicolumn{2}{c}{ Naira per hectare } \\
Cost / Returns Component & Mechanized & Non-Mechanized \\
\hline Total variable cost & $59,400.00$ & $60,500.00$ \\
Total fixed cost & $28,200.00$ & $13,200.00$ \\
Total cost & $87,600.00$ & $73,700.00$ \\
Total revenue & $144,000.00$ & $96,000.00$ \\
Gross margin & $56,400.00$ & $22,300.00$ \\
Net farm income & $28,200.00$ & $9,100.00$ \\
\hline Source: Field Survey 2013 & &
\end{tabular}

Farm Financial Ratio Analysis: Table 2 show that farmers in the study area expended a mean of $41 \%$ of the total revenue realized in paying for operating expenses incurred and $20 \%$ in fixed expenses under mechanized rice production. While the non mechanized expend $63 \%$ of the total revenue realized in paying for operating expenses and $14 \%$ in fixed expenses. The low fixed ratio under non mechanized rice production is an indication that farmers use traditional implements for farm operation, which have low purchasing cost as compare to machinery and lower depreciation overtime.

The mean gross ratio of 0.61 shows that $61 \%$ of the total revenue realized by farmers operating under mechanized farming goes to pay for both operating and fixed expenses. This figure is reasonable considering $39 \%$ of the total revenue that is accrued by the farmers under the mechanized rice production. While a gross margin of 0.77 show that $77 \%$ of the total revenue realized by farmers operating under non mechanized farming goes to pay for both operating and fixed expenses. This figure is higher than that of mechanized rice farmers, considering the $23 \%$ of the total revenue that is left for the farmers. The return per naira invested, which gives the benefit of accrued to every naira invested in rice production enterprise is another better measure of profitability. Mechanized farmers were found to obtained a higher return per naira invested of 1.64 than the non mechanized having 1.30. The high operation ratio in non mechanized farms should be expected as farmers do not reap enough from sale of the produce. 
Table 2: Farm financial analysis of Mechanized and Non Mechanized rice farmers in Nassarawa State.

\begin{tabular}{|c|c|c|}
\hline \multirow[t]{2}{*}{ Farm financial ratio component } & \multicolumn{2}{|c|}{ Ratios } \\
\hline & Mechanized & Non-Mechanized \\
\hline Operating & 0.41 & 0.63 \\
\hline Fixed & 0.20 & 0.14 \\
\hline Gross & 0.61 & 0.77 \\
\hline $\begin{array}{l}\text { Return on naira } \\
\text { Invested }\end{array}$ & 1.64 & 1.30 \\
\hline
\end{tabular}

Source: Field Survey 2013

Estimated Total Farm Output with Production Inputs: The result of Cob-Douglas production function which was used for analysis is presented in Table 3 . The result indicate that, the coefficient of farm size and fertilizer are positive and statistically significant at $(\mathrm{P}<0.1)$, indicating a direct relationship between the two inputs and non mechanized output. That of seed is negative and significant indicating inverse relationship, labour is not significant. The positive and significance influence of farm size and fertilizer on non mechanized rice farms total output implies that larger farms poses greater output, and the use of fertilizer is very important as the fallow period can not be accomplished. The negative and significance level of seed, may be due to the effect of late farm operation due to non availability of labour on the timing of planting, which partially explain the low total farm output and consequently farmers profit of non mechanized rice farmers. For mechanized farms, all the variables are positive and statistically significant, indicating a direct relationship between them and the farmers' output. The greater variation of $93.40 \%$ in total farm output among mechanized rice farmers indicate that the use of machinery made them more efficient in management and resource utilization than their non mechanized counterpart.

Table 3: Estimated Regression Equation for Total Farm Output $(\mathrm{Kg})$ with Production Inputs in Nasarawa State

\begin{tabular}{lcc}
\hline Estimated parameters & $\begin{array}{c}\text { System of farm } \\
\text { Non- Mechanized }\end{array}$ & $\begin{array}{c}\text { Operation } \\
\text { Mechanized }\end{array}$ \\
\hline Constant & $0.448^{\mathrm{NS}}$ & $-0.061^{\mathrm{NS}}$ \\
& $(1.254)$ & $(-39.428)$ \\
Farm size & $2.120^{*}$ & $4.20^{* *}$ \\
& $(204.995)$ & $(189.913)$ \\
Fertilizer & $0.244^{* * *}$ & $3.320^{* * *}$ \\
& $(0.193)$ & $(4.175)$ \\
Seed & $-0.144^{* * *}$ & $3.410^{* * *}$ \\
& $(-0.136)$ & $(7.161)$ \\
Labour & $0.944^{\mathrm{NS}}$ & $3.840^{* * *}$ \\
& $(0.972)$ & $(6.564)$ \\
Herbicide & - & $5.20^{* * *}$ \\
& & $(15.564)$ \\
$\mathrm{R}^{2}$ & 65.50 & 93.40 \\
\hline
\end{tabular}

Source: Field Survey 2013.

Note: Figure in bracket are standard errors

$* * *$ Significant at $\mathrm{P}<0.01$

** Significant at $\mathrm{P}<0.05$

* Significant at $\mathrm{P}<0.1$

Resource Use Efficiency Ratio: The result of resource use efficiency ratio in ratio in rice production is presented in Table 4. The result showed that both mechanized and non mechanized rice farmers used labour, farm size and seed inputs above economic optimum, indicating over utilization of these resources. However, mechanized rice farmers used these inputs close to economic optimum with efficiency ratio of $0.98,0.95$ and 0.94 for labour, farm size and seed respectively. Compare to $0.58,0.46$ and 0.71 for the same inputs for the same inputs used by non mechanized rice farmers. This is largely due to the use of mechanization. The disparity in labour is not unconnected with the over use of family labour and non availability of hired labour and the resource is not well managed. For the farm size, the mechanized farm with the advantage of ease and shorter time in cultivating larger farms made it more efficient than the non mechanized farms. In the same vein, the better efficiency in mechanized farm in utilizing seed is due to the technical know-how on the use of ploughingseed-broadcasting-harrowing combination which better utilized spacing and seed rate. Only the fertilizer resource was under utilized in both mechanized and non mechanized farms. The underutilization of fertilizer result may be due to the general high cost of the input which limits farmers' access to it. This finding agree with Idi (2004) that fertilizer resource is greater than unity, while labour, seed and farm size are less than unity. 
Table.4 Estimate of Marginal value product of mechanized and non mechanized rice production.

\begin{tabular}{|l|c|c|c|c|c|c|}
\hline \multirow{2}{*}{ Inputs } & Marginal Value Product & Marginal Factor Cost & \multicolumn{2}{l|}{ Efficiency Ratio } \\
\cline { 2 - 7 } & Mechanized & Non Mech & Mech & Non Mech & Mech & Non Mech \\
\hline Labour & 265.78 & 200.40 & 270.25 & 345.30 & 0.98 & 0.58 \\
\hline Farm size & 4394.38 & 1707.85 & 4670.40 & 3673.51 & 0.95 & 0.46 \\
\hline Seed & 45.81 & 32.32 & 48.29 & 45.43 & 0.94 & 0.71 \\
\hline Fertilizer & 144.60 & 2739.96 & 45.72 & 48.65 & 3.16 & 56.32 \\
\hline
\end{tabular}

Source: Field survey, 2013.

Optimum resource Use: The percentage adjustment in marginal value product of resource use for optimal use is presented in Table 5. The results reveal that, for optimum allocation of resources, labour (101.68\%), farm size $(106.28 \%)$ and seed $(105.41 \%)$ were over utilized in mechanized farms and adjustment need to be made to bridge the gap for optimal resource used. And also, for optimum allocation of resources, labour $(172.25 \%)$, farm size $(115.10 \%)$ and seed $(140.56 \%)$ were over utilized in non mechanized farms and adjustment need to be made to bridge the gap for optimal resource used. The result indicates that a lot need to be done to bridge the gap in non mechanized farms. Fertilizer having $(98 \%$ and $68 \%)$ was under utilized in both mechanized and non mechanized rice farms respectively, for economic optimum the gap need to be bridged. The finding however, agrees with that of Idiong (2005) who found that fertilizer did not contribute to the efficiency of rice production due to low usage of the input. The findings also agree with that of Ajao et al; (2005) that the output and income of farmers could be improved if resources were utilized at the existing technology. This requires the effort of the government to help provide the less privilege farmers with the present existing technology.

Table 5. Estimate of percentage adjustment of Marginal value product of mechanized and non mechanized rice production.

\begin{tabular}{|l|c|c|}
\hline \multirow{2}{*}{ Inputs } & \multicolumn{2}{|c|}{ Percentage adjustment required } \\
\cline { 2 - 3 } & Mechanized & Non Mechanized \\
\hline Labour & 101.68 & 172.25 \\
\hline Farm size & 106.28 & 115.10 \\
\hline Seed & 105.41 & 140.56 \\
\hline Fertilizer & 68.38 & 98.22 \\
\hline
\end{tabular}

Source: Field survey; 2013.

\section{Conclusion}

Production resources in the study area were found not to be efficiently utilized to optimum economic advantage for both mechanized and non mechanized rice farmers. Based on the result obtained it can be concluded that mechanized rice production is more efficient in resource utilization and subsequently more profitable. It is therefore, recommended that input such as fertilizer should be made available to the farmers by government. In addition, there should be policies to encourage the use of farm machineries to absorb the excess labour cost in rice production. It therefore, follows that increase rice production will be negatively affected, if government agencies do not made fertilizer available to farmer at subsidized rate and also encourage the less privilege into the use of farm machineries. This will enhance optimum use of resources with high returns over cost of production there by improving the standard of living.

\section{References}

[1]. Abdulsalam, Z. Edacha, E.O. and Mahmud, M.A. (1988): Economic Analysis of Factors Affecting Small Scale Farming in Zaria Area of Kaduna State. In: Ramalan, A. A (ed) Irrigation in Sustainable Agriculture. Proceedings of the $12^{\text {th }}$ National Irrigation and Drainage Seminar held at ABU Zaria, April 14-16. pp 222-226.

[2]. Ajao, A.O. Ajetomobi J .0. and Olarinde, L.O. (2005) "Comparative Efficiency of Mechanized and Non Mechanized Farms in Oyo State Nigeria: A Stochastic Frontier Approach” Journal of Human Ecology 18 (1): 27-30.

[3]. Alimi, T. (2000). Resource Use Efficiency in Food Production in Oyo State of Nigeria. Journal of Agriculture and Environment $1(1): 1-7$

[4]. Castle, E.N. (1987); Farm Business Management. The Decision Making Process. Macmillan Publishing Company Ne York: 413 Pp.

[5]. Daramola, B (2005) Government policies and competitiveness of Nigeria's rice economy. Paper presented at the workshop on rice policy and food security in sub-sahara Africa, organized by WARDA, Ctonou, Republic of Benin. $7^{\text {th }}-9^{\text {th }}$ Nov.

[6]. Defoer, T, Wopereis T.C.S; Jones, P.R; Lancon, P; Erenstein, O and Guei, R.G (2004) Chanllenges and technical opportunities for rice based production system for food security povertyalleviation in sub- sahara Africa. FAO Rice Conference, Rome, Italy. $12^{\text {th }}-$ $13^{\text {th }}$ Febuary.

[7]. Eke, C (2008) A Starving Giant Source Magazine, April, 28. Vol. 23 p3.

[8]. Fagade, S.O: and Nguyen, Y.N. (2001): Evolution of Irrigation Rice Yield in Sub Saharan Africa. In: Nwumi 1.A. (ed) Yield Gap and Productivity Decline in Rice Production. Programme of Expert Consultation F. A.O, Rome, Italy, 5-7 September. Pp 161-169.

[9]. FAO (Food and Agricultural Organization, 2003) Production year book, Rome.

[10]. http/www.Agnet. (2005): Sustainable Agricultural System for Small-Scale Farmers in Thailand: Implication for the Environment 1$2 \mathrm{Pp}$. 
[11]. Idi. S. (2003): Comparative Economics Analysis of Adopters and Non-Adopters of Sasakawa Rice Production Techniques in Dass, L.G.A Bauchi State, Unpublished M.Sc. Thesis Abubakar Tafawa Balewa University Bauchi. 46 Pp.

[12]. Idiong, I.C (2005) Estimation of farm level technical efficiency in small scale swamp rice production in cross river state of Nigeria. World journal of Agricultural Science. 3(5): 653-658

[13]. Johnson, D.T. (1982): The Business of Farming: A Guide to Farm Business Management in the Topics. Macmillan Press Limited, London $362 \mathrm{Pp}$,

[14]. Kay, R.D. (1981): Farm Management, Planning, Control and Implementation. MacGraw Hill -Tokyo 370 Pp.

[15]. Olagoke, M.A. (1991): Efficiency of resources use in rice Production System Anambra State. Nigeria. In: Doss, C.R. and Olson, C. (eds) Issues in African Rural Development. Winrocks International Institute for Agricultural Development Va. 303-319.

[16]. Olukosi, J. O and Erhabor, P.O. (1988): Introduction to Farm Management Economics. Agitab Publishers Limited, Zaria. 112 Pp.

[17]. Olukosi, J. O and Ogunbile, A.O. (1989): Introduction to Farm Agricultural Production Economics: Principles and Application Agitab Publishers Limited, Zaria Nigeria. $202 \mathrm{Pp}$.

[18]. Sani, R,M. (1996): Economics Analysis of Small Scale egg Production: A Case Study of Gombe Local Government Area Gombe State. B. Agric (Tech) Project. Abubakar Tafawa Balewa University, Bauchi 73 Pp.

[19]. Suleiman, H.R (2008): Comparative Analysis of Mechanized and Non-Mechanichanized Rice Farms: A Study of Labour Saving Technology in Lafia LGA of Nasarawa State. Unpuplished M.Sc. Thesis. Abubakar Tafawa Balewa University Bauchi. 67pp. 